\title{
Effect of Slag Fineness and Curing Conditions on the Mechanical Properties of Alkali-Activated Blast Furnace Slag Mortars
}

\author{
Hasan Biricik*, Işı1 Sanrı Karapinar* \\ * Department of Civil Engineering, Faculty of Engineering and Natural Sciences, Maltepe University, Istanbul, Turkey \\ (hasanbiricik43@gmail.com, isilkarapinar@maltepe.edu.tr) \\ IŞs1 Sanrı Karapınar, Maltepe University, Istanbul, Turkey \\ Tel: +90 21662610 50, isilkarapinar@maltepe.edu.tr
}

Received: 07.04.2021 Accepted: 03.05.2021

\begin{abstract}
The main objective of this experimental study was to investigate the effect of the slag fineness on the compressive and flexural strengths of ground granulated alkali-activated blast furnace slag mortars. Two types of alkali-activated mortar mixtures were produced using blast furnace slags having the Blaine fineness of $400 \mathrm{~m}^{2} / \mathrm{kg}$ and $600 \mathrm{~m}^{2} / \mathrm{kg}$. Three curing methods; water curing, air curing and outdoor conditions, were applied to the samples. Compressive strengths and flexural strengths of the mixtures were determined at various ages and capillary water absorption tests were also performed. Test results confirm that increasing the fineness of slag had an important effect on the properties obtained. The curing method is also an important factor affecting the results.
\end{abstract}

Keywords- Blast furnace slag; alkali activation; fineness; curing conditions; mechanical strength; capillary water absorption.

\section{Introduction}

Alkali-activated materials have received much attention in the past decade due to their promising potential of replacing Portland cement. As is well known, the cement industry is one of the major producers of $\mathrm{CO}_{2}$ emissions. Since the manufacturing process of Portland cement contributes considerably to $\mathrm{CO}_{2}$ emissions, with the purpose of reducing the carbon footprint, many attempts have been made to find alternative binders to decrease the amount of cement used. Alkali-activated binders have been considered to be more environment-friendly due to the fact that the $\mathrm{CO}_{2}$ emission is less compared to Portland cement $[1,2]$. Aluminosilicates which are mostly reused industrial by-products and wastes are used as precursors in the production of alkali-activated binders. Many pozzolanic by-products are being used in cement as an alkali-activated binder, however, blast furnace slag is one of the most reused materials for this process resembling the Portland cement in chemical composition[3]. A growing body of literature has been investigated the mechanical and microstructural properties of alkali-activated cementitious composites blended by blast furnace slag[4-9]. The studies have shown that as the amount of blast furnace slag increases, an improvement in compressive strength occurs. On the other hand, it was reported that the dosages of the slag affect the workability and setting time of the cementitious composites[10, 11]. Also, the fineness and the curing conditions significantly affect the fresh and hardened properties as well[12]. In a study, it was noted that increasing the fineness of blast furnace slag resulted in the development of the strength of the binder by 50\%[13]. Also, slags having two different blaine fineness were used for the alkali-activated binder and the development in strength due to the increase in blaine fineness was reported[14]. The use of blast furnace slag in cementitious composites is detailed by three grades in ASTM C 989 showing its potential as supplementary cementitious material[15]. The grinding process has an important effect on the particle size of the blast furnace slag. The relationship between the particle size and the specific surface area has significant implications in terms of the pozzolanic activity of the granulated blast furnace slag[16]. As stated, there has been an enhancement in strength due to the increase in fineness of the blast furnace slag. This observed increase in strength is explained by the increase in the specific surface area inducing an improvement in the reactivity of the blast furnace slag. Also, in recent studies, cementitious composites including granulated blast furnace slag activated with sodium carbonate and sodium silicate were compared and the changes in mechanical strength and setting time were discussed[17, 18]. Also, another study has used sodium carbonate and sodium silicate (waterglass) as activators to investigate the mechanical strength of alkali-activated blast furnace slag and waste of ceramic bricks and concluded that the axial compressive strength has improved for the 
cementitious composites in which sodium silicate was used as the activator[19].

In this experimental study, blast furnace slag-based geopolymer mortars having different particle sizes were prepared using both sodium hydroxide $(\mathrm{NaOH})$ and sodium silicate $\left(\mathrm{Na}_{2} \mathrm{SiO}_{3}\right)$ as activators and the effect of blast furnace slag fineness on compressive and flexural strength of alkaliactivated mortars was investigated under different curing conditions.

\section{Experimental Study}

\subsection{Materials}

Blast furnace slags having two fineness values were used. Same ground blast furnace slag was used and was grounded in a laboratory ball mill. The initial Blaine fineness of the slag was $400 \mathrm{~m}^{2} / \mathrm{kg}$ and was increased to $600 \mathrm{~m}^{2} / \mathrm{kg}$ after the grinding. Chemical compositions of the slags are shown in Table 1 and some of their physical properties are given in Table 2.

Table 1. Chemical compositions of the blast furnace slags.

\begin{tabular}{|c|c|c|}
\hline $\begin{array}{c}\text { Oxide } \\
\text { Composition (\%) }\end{array}$ & $\begin{array}{c}\text { Slag BSA: } \\
400 \mathrm{~m}^{2} / \mathrm{kg}\end{array}$ & $\begin{array}{c}\text { Slag BSA: } \\
600 \mathrm{~m}^{2} / \mathrm{kg}\end{array}$ \\
\hline $\mathrm{SiO}_{2}$ & 38.41 & 37.78 \\
\hline $\mathrm{Al}_{2} \mathrm{O}_{3}$ & 10.22 & 10.07 \\
\hline $\mathrm{Fe}_{2} \mathrm{O}_{3}$ & 1.53 & 1.58 \\
\hline $\mathrm{CaO}$ & 37.71 & 37.56 \\
\hline $\mathrm{MgO}_{\mathrm{SO}_{3}}$ & 7.88 & 8.08 \\
\hline $\mathrm{Cl}^{-}$ & 0.63 & 0.65 \\
\hline $\mathrm{Na}_{2} \mathrm{O}$ & 0.33 & 0.256 \\
\hline $\mathrm{K}_{2} \mathrm{O}$ & 0.82 & 0.32 \\
\hline Loss on ignition & 2.05 & 0.82 \\
\hline
\end{tabular}

Table 2. Some physical properties of the blast furnace slag.

\begin{tabular}{|c|c|c|}
\hline Property & $\begin{array}{c}\text { Slag BSA: } \\
400 \mathrm{~m}^{2} / \mathrm{kg}\end{array}$ & $\begin{array}{c}\text { Slag BSA: } \\
600 \mathrm{~m}^{2} / \mathrm{kg}\end{array}$ \\
\hline Density & 2.88 & 2.88 \\
\hline $\begin{array}{c}\text { Blaine surface area } \\
\left(\mathrm{m}^{2} / \mathrm{kg}\right)\end{array}$ & 400 & 600 \\
\hline $\begin{array}{c}\text { Retained on } 200 \mu \mathrm{m} \\
\text { sieve (\%) }\end{array}$ & 0.0 & 0.0 \\
\hline $\begin{array}{c}\text { Retained on } 90 \mu \mathrm{m} \\
\text { sieve (\%) }\end{array}$ & 0.0 & 0.4 \\
\hline $\begin{array}{c}\text { Retained on } 45 \mu \mathrm{m} \\
\text { sieve (\%) }\end{array}$ & 1.0 & 0.0 \\
\hline
\end{tabular}

Figure 1 demonstrates that the average particle size decreases by grinding of the slag. The initial average particle was $45 \mu \mathrm{m}$, which was reduced to $8 \mu \mathrm{m}$ after grinding.

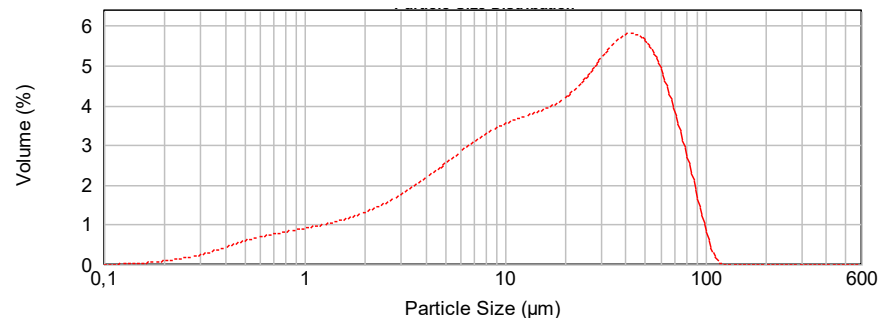

(a)

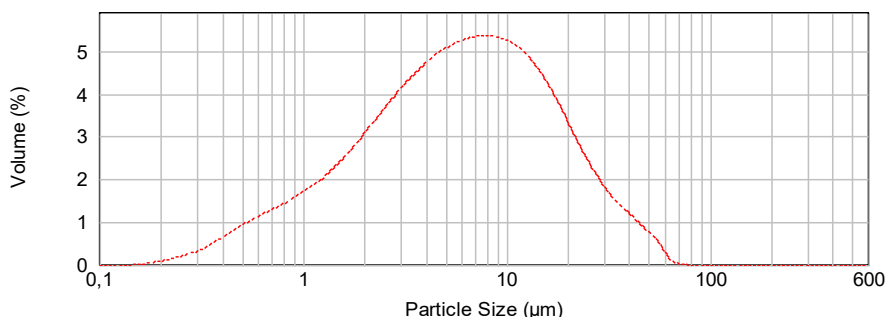

(b)

Figure 1. Particle size distributions of blast furnace slags (a) before grinding (b) after grinding.

In order to activate the ground granulated blast furnace slag, two different alkaline materials; sodium hydroxide and sodium silicate were utilized. Both of the activators were classified as the technical grade. Sodium hydroxide was in solid form and was dissolved in distilled water before using in the mixtures. Sodium silicate and sodium hydroxide solutions were used together for the activation of the blast furnace slags. The amounts of these activators in the solution by weight were $8 \%$ and $27 \%$, respectively. The modulus of sodium silicate was 3 . The density of the sodium hydroxide was ranging from 0.93 $\mathrm{g} / \mathrm{cm}^{3}$ whereas the density of sodium silicate solution was 1.33 $\mathrm{g} / \mathrm{cm}^{3}$. The same siliceous natural sand with a maximum particle size of $4 \mathrm{~mm}$ and a specific gravity of $2.563 \mathrm{~g} / \mathrm{cm}^{3}$ was used in the study.

\section{2. $\quad$ Mixtures}

Two mortar mixtures were produced in the experimental work. The mixture proportions are given in Table 3 . The mixtures were designated as BFS4 and BFS6 where BFS indicates blast furnace slag and the numbers following BFS show the fineness of the slag. For instance, BFS4 shows that the mixture was produced with slag having the Blaine fineness of $400 \mathrm{~m}^{2} / \mathrm{kg}$. Both of the mixtures were stirred in a laboratory mixer. $160 \mathrm{x}$ $40 \times 40 \mathrm{~mm}$ steel molds were used for casting of all specimen series and were unmolded after 24 hours.

\subsection{Curing Conditions}

After demolding, three different curing conditions were applied;

i) Standard water curing at $20^{\circ} \mathrm{C}$, or

ii) Laboratory air curing at $20 \pm 3^{\circ} \mathrm{C}$ and $60 \%$ relative humidity, or 
iii) Outdoor conditions with an average temperature of $15 \pm 5^{\circ} \mathrm{C}$ and varying humidity (such as rain).

These curing conditions were applied until testing.
The flexural strengths of the mixtures are given in Table 4. In this table, the letters $\mathrm{O}, \mathrm{L}$ and $\mathrm{W}$ represent the curing conditions

Table 3. Mixture proportions.

\begin{tabular}{|c|c|c|c|c|c|c|}
\hline Mixture code & $\begin{array}{c}\text { Blast furnace slag } \\
\left(\mathrm{kg} / \mathrm{m}^{3}\right)\end{array}$ & $\begin{array}{c}\text { Water } \\
\left(\mathrm{kg} / \mathrm{m}^{3}\right)\end{array}$ & $\begin{array}{c}\mathrm{Na}(\mathrm{OH}) \\
\left(\mathrm{kg} / \mathrm{m}^{3}\right)\end{array}$ & $\begin{array}{c}\mathrm{Na}_{2} \mathrm{SiO}_{2} \\
\left(\mathrm{~kg} / \mathrm{m}^{3}\right)\end{array}$ & $\begin{array}{c}\text { Sand } \\
\left(\mathrm{kg} / \mathrm{m}^{3}\right)\end{array}$ & $\begin{array}{c}\text { Unit weight } \\
\left(\mathrm{kg} / \mathrm{m}^{3}\right)\end{array}$ \\
\hline BFS4 & 466 & 233 & 32.6 & 79.2 & 1398 & 2209 \\
\hline BFS6 & 468 & 208 & 32.8 & 79.6 & 1404 & 2192 \\
\hline
\end{tabular}

\subsection{Testing}

Bending tests of the samples were made according to TS EN 196-1[20]. After this bending test, the compressive strength tests were conducted on the prism halves having a $40 \times 40 \mathrm{~mm}$ cross-section. The compressive strengths of the specimens were also obtained with respect to TS EN 196-1. The mechanical properties of the specimens were tested at the ages of $3,7,28$ and 56 days. To determine the permeability properties, capillary water absorption tests were made on the mixtures at the age of 56 days according to the requirements of TS EN 480-5 [21].

\section{Results and Discussion}

\subsection{Flexural Strengths}

where $\mathrm{O}$ denotes the outdoor curing, $\mathrm{L}$ indicates laboratory air curing and $\mathrm{W}$ stands for water curing.

Figures 2 and 3 illustrate the flexural strengths of the mixtures produced with slag of 400 and $600 \mathrm{~m}^{2} / \mathrm{kg}$ fineness, respectively. As presented in these figures, water curing resulted in higher strengths. The flexural strength of the water cured samples were approximately 65 to $80 \%$ higher than the outdoor conditions. These results confirm that water is essential for the continuation of the hydration reactions. The 28-day and 56-day strengths obtained for the outdoor exposed specimens containing $600 \mathrm{~m}^{2} / \mathrm{kg}$ slag (BFS 6O), were lower than 7-day strengths. This may be due to the fluctuations in the humidity of the outdoor conditions. Reductions in humidity might have caused possible damages, such as micro-cracks at aggregate-paste interfaces, which may reduce the strength.

Table 4. Flexural strengths of the mixtures.

\begin{tabular}{|c|c|c|c||c|c|c|}
\hline \multirow{2}{*}{$\begin{array}{c}\text { Testing Age } \\
\text { (Days) }\end{array}$} & \multicolumn{7}{|c|}{ Flexural strength (MPa) } \\
\cline { 2 - 7 } & BFS 4O & BFS 4L & BFS 4W & BFS 6O & BFS 6L & BFS 6W \\
\hline 3 & 0.8 & 1.0 & 2.8 & 4.6 & 4.8 & 5.7 \\
\hline 7 & 2.8 & 2.1 & 4.3 & 4.8 & 5.7 & 5.8 \\
\hline 28 & 3.2 & 3.0 & 5.8 & 4.1 & 5.5 & 6.8 \\
\hline 56 & 3.3 & 4.1 & 6.5 & 4.6 & 5.9 & 7.0 \\
\hline
\end{tabular}

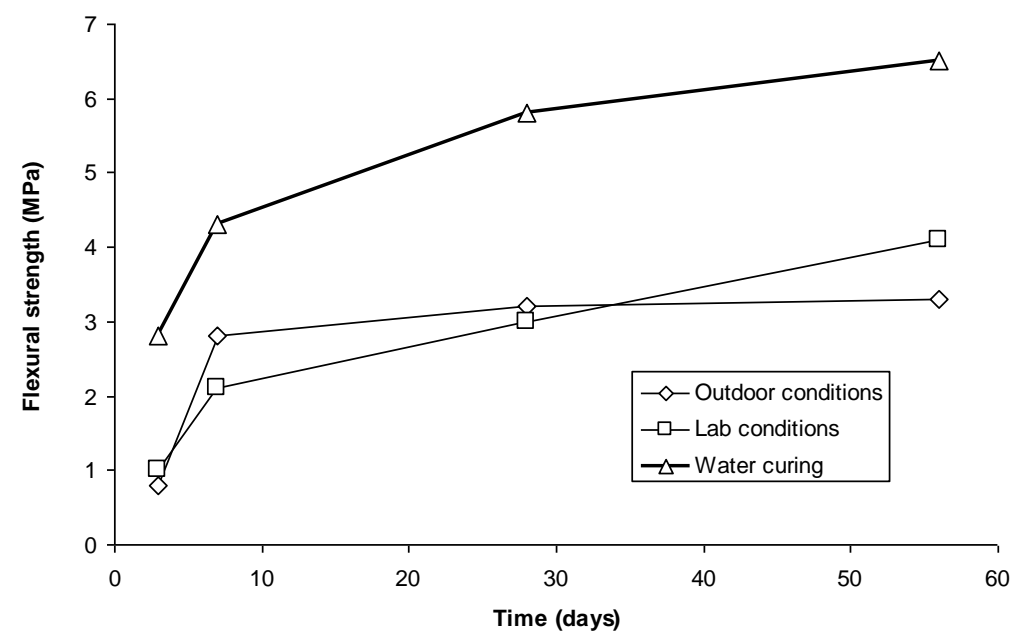

Figure 2. Flexural strengths of the mixtures produced with slag of $400 \mathrm{~m}^{2} / \mathrm{kg}$ fineness. 


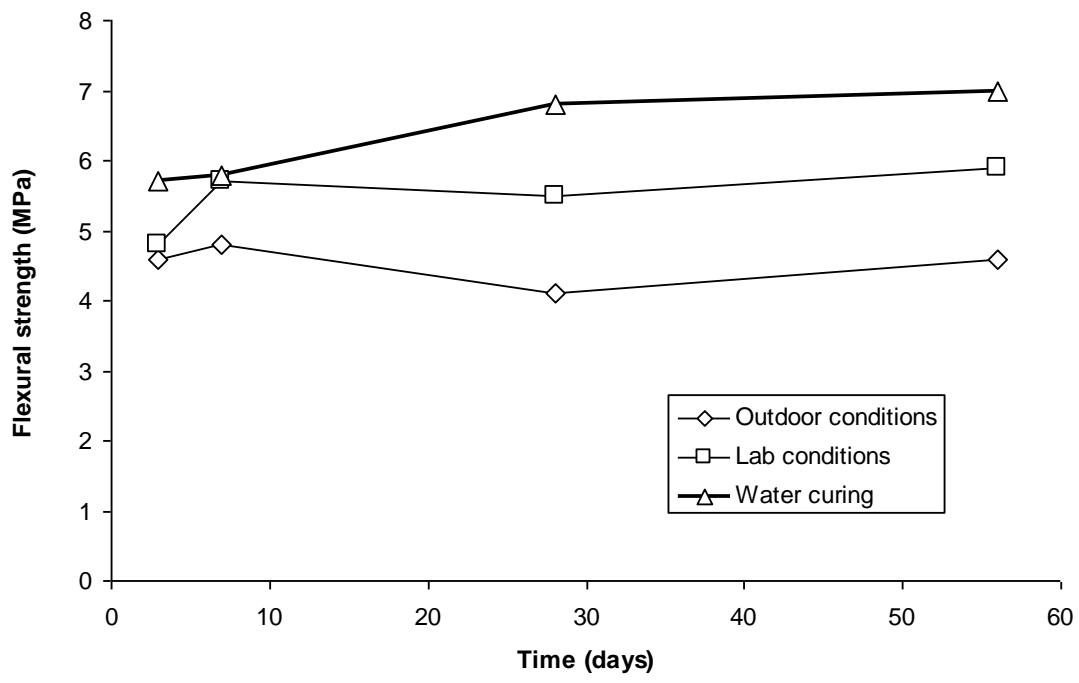

Figure 3. Flexural strengths of the mixtures produced with slag of $600 \mathrm{~m}^{2} / \mathrm{kg}$ fineness.

When the effect of slag fineness is compared, it can be seen that the mixtures containing finer slag had higher strength values.

\subsection{Compressive Strengths}

Compressive strengths of the mixtures are shown in Table 5, and also in Figures 4 and 5. Similar to the flexural test results, the water-cured specimens achieved higher compressive strengths, as expected. Depending on these findings, it may be deduced that the effect of curing conditions for alkali-activated mixtures is similar to those for normal concretes.

Increasing the fineness of slag from $400 \mathrm{~m}^{2} / \mathrm{kg}$ to $600 \mathrm{~m}^{2} / \mathrm{kg}$ resulted in higher compressive strength. For example, after 28 days of water curing; the compressive strength of the mixture produced with $400 \mathrm{~m}^{2} / \mathrm{kg}$ was $38 \mathrm{MPa}$, but that with $600 \mathrm{~m}^{2} / \mathrm{kg}$ was $60.3 \mathrm{MPa}$, which corresponds to a strength increase of approximately $60 \%$. This strength increase was more

Table 5. Compressive strengths of the mixtures.

\begin{tabular}{|c|c|c|c||c|c|c|}
\hline \multirow{2}{*}{$\begin{array}{c}\text { Testing Age } \\
\text { (Days) }\end{array}$} & \multicolumn{6}{|c|}{ Compressive strength (MPa) } \\
\cline { 2 - 7 } & BFS 4O & BFS 4L & BFS 4W & BFS 6O & BFS 6L & BFS 6W \\
\hline 3 & 4.5 & 6.9 & 12.2 & 25.1 & 25.9 & 27.5 \\
\hline 7 & 16.1 & 14.8 & 21.1 & 33.7 & 43.1 & 47.7 \\
\hline 28 & 18.8 & 26.6 & 38.0 & 38.7 & 54.6 & 60.3 \\
\hline 56 & 46.9 & 50.5 & 58.5 & 40.5 & 58.7 & 63.6 \\
\hline
\end{tabular}

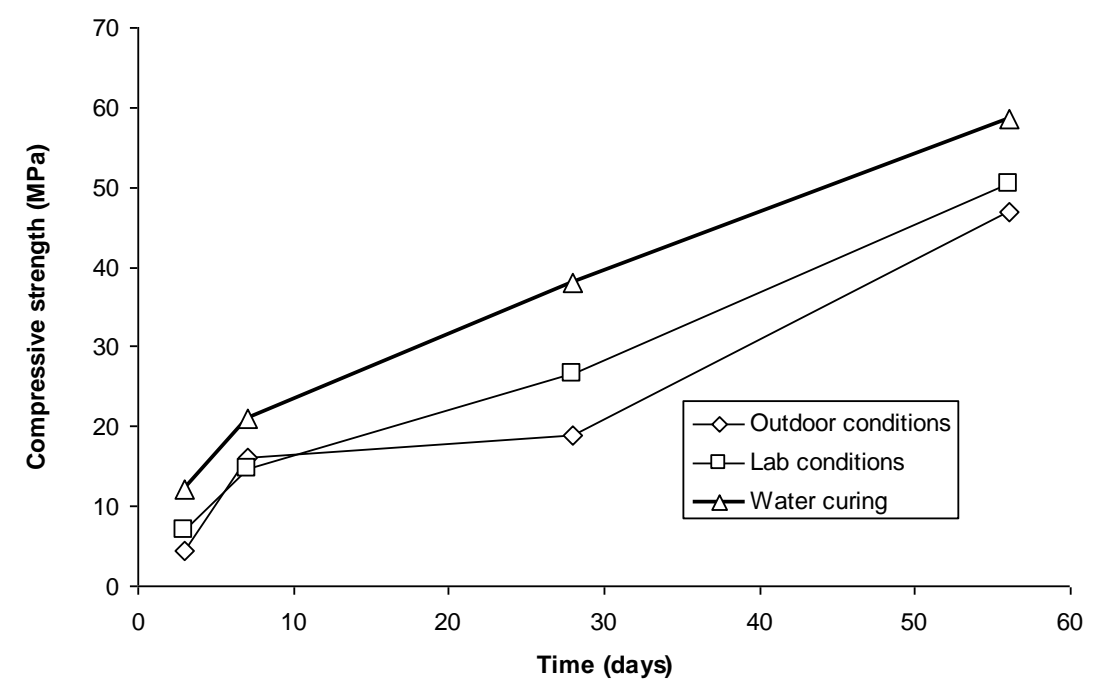

Figure 4. Compressive strengths of the mixtures produced with slag of $600 \mathrm{~m}^{2} / \mathrm{kg}$ fineness. 


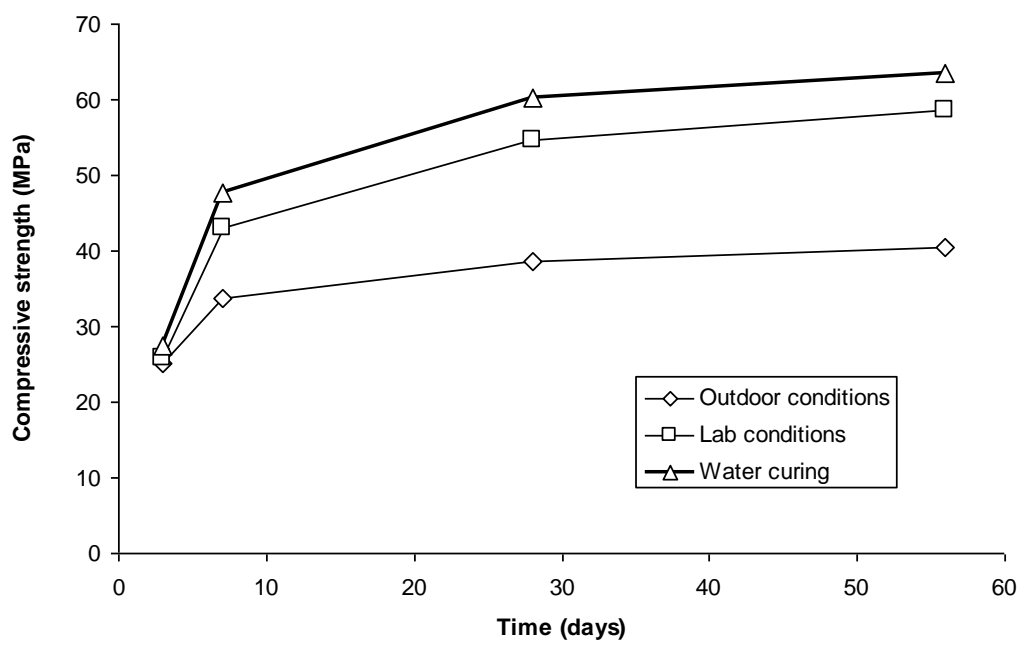

Figure 5. Compressive strengths of the mixtures produced with slag of $600 \mathrm{~m}^{2} / \mathrm{kg}$ fineness.

significant for early ages. Similar strength increases were obtained also for the other curing methods.

\subsection{Capillary Water Absorption}

Table 6 displays the results of the capillary water absorption test carried out with respect to TS EN 480-5. These tests were performed only at the age of 56 days. As seen in Figure 6, the fineness of slag had a significant effect on the capillary water absorption, especially for laboratory air curing and water curing. The reduction in capillarity was more than $60 \%$ for these two curing methods.

Table 6. Capillary water absorption of the mixtures.

\begin{tabular}{|c|c|c|c|}
\hline \multirow{2}{*}{$\begin{array}{l}\text { Fineness of slag } \\
\qquad\left(\mathrm{m}^{2} / \mathrm{kg}\right)\end{array}$} & \multicolumn{3}{|c|}{$\begin{array}{c}\text { Capillary coefficient } \\
\left(\mathrm{cm}^{2} / \mathrm{s}\right)\end{array}$} \\
\hline & $\begin{array}{l}\text { Outdoor } \\
\text { conditions }\end{array}$ & $\begin{array}{l}\text { Laboratory } \\
\text { air curing }\end{array}$ & $\begin{array}{l}\text { Water } \\
\text { curing }\end{array}$ \\
\hline 400 & 8.6 & 7.4 & 5.8 \\
\hline
\end{tabular}

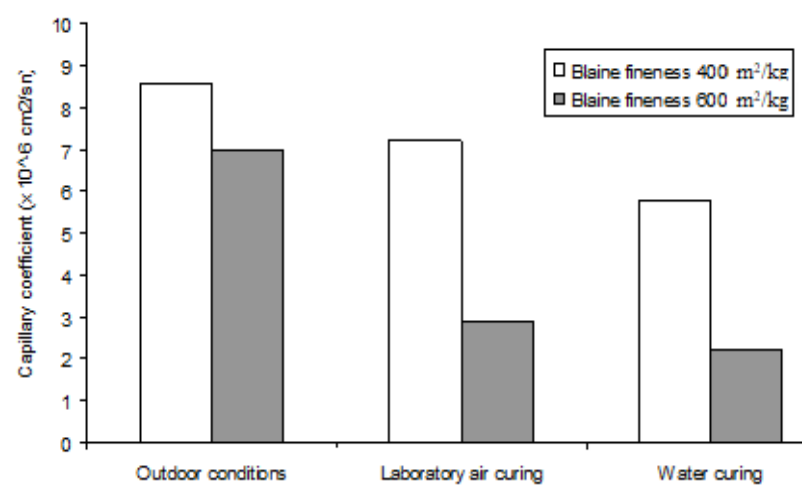

Figure 6. Capillary water absorption of the mixtures.

\section{Conclusion}

This experimental study has investigated the effect of slag fineness and type of curing on the mechanical properties of alkali-activated blast furnace slag mortar. Two different blaine fineness of $400 \mathrm{~m}^{2} / \mathrm{kg}$ and $600 \mathrm{~m}^{2} / \mathrm{kg}$ for the blast furnace slag were used and three kinds of curing methods, namely, water curing, air curing and outdoor conditions, were applied to the mortar samples. They were alkali-activated by both sodium hydroxide $(\mathrm{NaOH})$ and sodium silicate $\left(\mathrm{Na}_{2} \mathrm{SiO}_{3}\right)$. In conclusion, the compressive strength of the alkali-activated mortar increased significantly as the fineness of the blast furnace slag was increased. Also, higher flexural strengths were obtained by using a finely ground slag. It is observed that the fineness of slag also affected the capillary water absorption of the mixtures. The reduction in capillarity was more than $60 \%$ for laboratory air curing and water curing. On the other hand, according to all the test results obtained, the water-cured samples achieved the best results.

\section{References}

[1] X. Y. Zhuang, L. Chen, S. Komarneni, C. H. Zhou, D. S. Tong, H. M. Yang, W. H. Yu and H. Wang, "Fly ash-based geopolymer: clean production, properties and applications", J. Clean. Prod., vol. 125, pp. 253-267, 2016.

[2] T.-A. Kua, M. A. Imteaz, A. Arulrajah and S. Horpibulsuk, "Environmental and economic viability of Alkali Activated Material (AAM) comprising slag, fly ash and spent coffee ground”, Int. J. Sustain. Eng., vol. 12, pp. 223-232, 2019.

[3] M. H. Samarakoon, P. G. Ranjith, T. D. Rathnaweera and M. S. A. Perera, "Recent advances in alkaline cement binders: a review", J. Clean. Prod., vol. 227, pp. 70-87, 2019. 
[4] S. A. Bernal , R. M. de Gutiérrez, A. L. Pedraza, J. L. Provis, E. D. Rodriguez, S. Delvasto, "Effect of binder content on the performance of alkali-activated slag concretes", Cement Concrete Res., vol. 41, pp. 1-8, 2011.

[5] M. O. Yusuf, M. A. Megat Johari, Z. A. Ahmad and M. Maslehuddin, "Performance of different grades of palm oil fuel ash with ground slag as base materials in the synthesis of alkaline activated mortar", J. Adv. Concr. Technol., vol. 12, pp. 378-387, 2014.

[6] N. R. Rakhimova and R. Z. Rakhimov, "Alkali-activated cements and mortars based on blast furnace slag and red clay brick waste", Mater. Des., vol. 85, pp. 324-331, 2015.

[7] M. Nasir, M. J. M. Azmi, M. O. Yusuf, M. Maslehuddin, M. A. Al-Harthi and D. Hatim, "Impact of slag content and curing methods on the strength of alkaline-activated silicomanganese fume/blast furnace slag mortars", Arabian J. Sci. Eng., 44, pp. 8325-8335, 2019.

[8] G. F. Huseien, A. R. M. Sam, K. W. Shah, J. Mirza and Tahir M. Md, "Evaluation of alkali-activated mortars containing high volume waste ceramic powder and fly ash replacing GBFS", Construct. Build. Mater., 210, pp. 78-92, 2019.

[9] I. H. Aziz, M. M. A. B. Abdullah, M. A. A. M. Salleh, E. A. Azimi, J. Chaiprapa and A. V. Sandu, "Strength development of solely ground granulated blast furnace slag geopolymers", Construct. Build. Mater., vol. 250, 118720, 2020.

[10] M. Soutsos, A. P. Boyle, R. Vinai, A. Hadjierakleous and S. J. Barnett, "Factors influencing the compressive strength of fly ash based geopolymers", Construct. Build. Mater., 110 , pp. 355-368, 2016.

[11] M. Ibrahim and M. Maslehuddin, "An overview of factors influencing the properties of alkali-activated binders", $J$. Clean. Prod., vol. 286, 124972, 2021.

[12] A. M. Humad, K. Habermehl-Cwirzen and A. Cwirzen, "Effects of fineness and chemical composition of blast furnace slag on properties of alkali-activated binder", Materials, vol. 12, 3447, 2019.

[13] A.R. Brough, M. Holloway, J.M. Sykes and A. Atkinson, "Sodium silicate-based alkali-activated slag mortars: Part II. The retarding effect of additions of sodium chloride or malic acid", Cement Concr. Compos., vol. 30, pp. 13751379, 2000.

[14] M. Saedi, K. Behfarnia and H. Soltanian, "The effect of the blaine fineness on the mechanical properties of the alkali-activated slag cement", J. Build. Eng., vol. 26, 100897, pp. 1-8, 2019.

[15] ASTM C 989-2018, Standard specifications for ground granulated blast - furnace slag for use in concrete and mortars, The American Society for Testing and Materials, Pennsylvania, 2018.

[16] R. D. Hooton. The Reactivity and Hydration of Blast Furnace Slag, in Supplementary Cementing Materials for Concrete, Malhotra, V.M. ed., Canada Center for Mineral and Energy Technology (CANMET), 1987, pp. 247-330.

[17] A. M. Humad, J. L. Provis and A. Cwirzen, "Alkali activation of a high MgO GGBS - fresh and hardened properties", Mag. Concr. Res., vol. 70, pp. 1256-1264, 2018.

[18] A. O. Pehlivan, "Effect of alkali content and activator modulus on mechanical properties of alkali activated mortars", Karaelmas Sci. Eng. J., vol. 10, pp. 177-185, 2020.

[19] N. R. Rakhimova and R. Z. Rakhimov, "Alkali-activated cements and mortars based on blast furnace slag and red clay brick waste", Mater. Des., 85, pp. 324-331, 2015.

[20] TS EN 196-1, Methods of Testing Cement-Part 1: Determination of strength, Turkish Standards Institute, Ankara, Turkey, 2002.

[21] TS EN 480-5, Admixtures for concrete, mortar and groutTest methods-Part 5: Determination of capillary absorption, Turkish Standards Institute, Ankara, 2008. 